\title{
The Effectiveness of Environmental Assessment as a Sustainable Development Tool in Developing Countries: Case of Cameroon
}

\author{
Nchia Peter Ghong \\ Ministry of Environment, Nature Protection and Sustainable Development, Cameroon \\ Department of Agriculture and Environmental Engineering, College of Technology \\ University of Bamenda, P.O. Box 39, Bambili, Cameroon \\ E-mail: nchiapg@yahoo.com
}

Received: December 22, 2020 Accepted: January 2, $2021 \quad$ Published: February 10, 2021

doi:10.5296/emsd.v10i1.18291 URL: https://doi.org/10.5296/emsd.v10i1.18291

\begin{abstract}
In the last few decades, there has been increased worldwide awareness of the necessity to consider development from a holistic perspective, for human development without adequate environmental protection is undermined. Cameroon, like many other developing countries has made great strides in establishing and putting in place an environmental assessment system to mainstream environmental concerns into development initiatives. The full realization of this goal, however, depends on the effectiveness of the exercise which hinges principally on the provisions of relevant legislation, the institutional framework, the procedure and practice of the assessment process. Environmental assessment in many developing countries is fraught with a plethora of setbacks which can jeopardize the full contribution of the exercise to the attainment of the sustainable development goals, if not taken care of. Based on experience and field research, this study examines the current practice of environmental assessment in Cameroon, the difficulties encountered in developing countries, the chances of environmental assessment contributing to sustainability and makes recommendations on how to improve the practice in developing countries.
\end{abstract}

Keywords: Environmental protection, Development, Developing countries, Sustainability, Cameroon

\section{Introduction}

Poverty and environmental degradation are intricately linked in a vicious circle, thus sustainable development and poverty alleviation can hardly be attained without 
environmental protection. The drive, then, is to put environmental concerns on par with economic and social considerations in development initiatives to guarantee inter-generational justice (Abaza et al., 2004; Barasa, 2016). In the 1992 UN Conference on Environment and Development, held in Rio de Janero, Brazil, the international community took the commitment to ensure that development be considered holistically so that it is safe, durable and beneficial to all; thereby formally bringing the concept of sustainable development into the lime-light (United Nations, 1992). The relevance of environmental concerns in relation to sustainability was further buttressed in the adoption of the sustainable development goals (SDGs) in 2015 (United Nations, 2016).

As stated in Principle 17 of the Rio Declaration (United Nations, 1992), participating states were requested to incorporate environmental assessment into development efforts. Since then, there has been an upsurge in the adoption of legislation at national levels, that institute the conduct of environmental assessment in developing countries which was already a practice in the developed countries and few developing countries. Wood (2003) posits that by the start of the $21^{\text {st }}$ century, about 110 low- and middle income countries were already practicing environmental assessment. Examples being Albania, Chile, the Czech Republic, Egypt, India, Jordan, Lesotho, Malaysia, South Africa, Swaziland, Tanzania and Zimbabwe. Others, such as Cameroon were still to make environmental assessment mandatory.

Just like with the meaning of the concept of the environment, there equally exist slight variations in the appellation and practice of environmental assessment as well as in its definition. Parker and Corbit (1993, p. 208) define environmental assessment as "The systematic identification and evaluation of the potential impacts of proposed projects, plans, programs, policies, or legislative actions upon the physical-chemical, biological, cultural and socio-economic components of the environment". It can be broadly divided into two forms depending on the level and timing of its application. Strategic Environmental Assessment (SEA) is applied at the level of policy, plan and programme (PPP) while Environmental Impact Assessment (EIA) is applied at the project level (Alshuwaikhat, 2005; Partidário, 2003). Sadler and Verheem (1996) in Sadler (2001, p. 11) define SEA as "A systematic process for evaluating the environmental consequences of proposed policy, plan or programme initiatives in order to ensure they are fully included and appropriately addressed at the earliest appropriate stage of decision-making on par with economic and social considerations".

The efforts made by developed nations to promote environmental protection through the conduct of environmental assessments could be compromised if developing nations are not committed, given that some environmental impacts are transboundary in nature with regional or global effects. The need for effective environmental assessment in developing countries can, therefore, not be over-emphasized; bearing in mind that developing countries cover about three quarters of the world's land surface area and contains about $90 \%$ of the world's population (Wood, 2003).

Cameroon joined the global trend in 2005 when the conduct of EIA became mandatory in the country. The few EIAs conducted in the country hitherto, were on the demand of donors or 
development agencies (Alemagi et al., 2007; Bitondo, 2000). These authors and others, for instance, Nguene et al. (2012) and Ngouana Kengne (2009) have described aspects of what obtained as the EIA process in Cameroon before the putting in place of the current legislation governing the exercise in Cameroon. None, to the best of our knowledge has described the EIA process in Cameroon in the present dispensation. This paper, therefore, seeks to highlight the legislation, administration and practice of environmental assessment in Cameroon, the factors that affect the effectiveness of the exercise in Cameroon and other developing countries and situate the carrying out of environmental assessment in developing countries within the sustainability agenda.

Secondary data was collected by exploiting the country's pieces of legislation relating to environmental assessment, the review of three EIA reports and registers of public hearing for EIA studies carried out in the country and other existing literature. Primary data is from personal experience from the involvement in the EIA process in the country, the administration of unstructured interviews to some key stakeholders. Five members each of the populations in the vicinity of project sites for five separate studies were interrogated on their perception of the extent to which the views expressed during consultations were taken into consideration in the production of the reports and implementation of the projects. Three consultants, five staff members of the Ministry in charge of the Environment (supervisory authority of the EIA process) ranking as sub-directors and two university lecturers were questioned on their appraisal of the efficacy of the environmental assessment process in Cameroon, in relation to the generic process and compliance with regulations. The response from respondents were used to establish the strengths and weaknesses of the environmental assessment process in Cameroon.

\section{Framework of Environmental Assessment in Cameroon}

\subsection{Institutional Framework}

On the heels of the Rio Summit, the institutions in Cameroon charged with the elaboration, implementation and evaluation of policy on environment and nature protection, geared toward sustainable development have witnessed great evolution. In line with the roadmap set by Agenda 21, that environmental issues be mainstreamed into the development agenda, the Ministry of Environment and Forestry (MINEF) was created in 1994 (Alemagi et al., 2007). A permanent Secretariat with a Department for Sustainable Development was established in MINEF in 1996 (Bitondo, 2000). In 2004, MINEF was split, giving birth to the Ministry of Environment and Nature Protection (MINEP) that was organized by Decree $\mathrm{N}^{\mathrm{o}} 2005 / 117$ of 14 April 2005 modified by Decree $N^{\circ} 2005 / 496$ of 31 December 2005. To buttress the role of the Ministry in contributing to sustainable development in the country, MINEP was in 2011 transformed to the Ministry of Environment, Nature Protection and Sustainable Development (MINEPDED - Ministère de l'Environnement, de la Protection de la nature et du Développement Durable) organized by Decree $\mathrm{N}^{\mathrm{o}} 2012 / 431$ of 1 st October 2012. MINEPDED is the coordinating and regulatory body of environmental assessment in Cameroon. It is assisted in this function by an Inter-Ministerial Committee for Environment (ICE) and in its follow-up task by Divisional Follow-up Committees and environmental units 
in the sectorial Ministries and government agencies.

\subsection{Legal Framework}

The legislation or aspects thereof that govern the conduct of EIA in Cameroon have equally witnessed tremendous changes in the post Rio Summit era. The need for an EIA was first vaguely stated in Law $\mathrm{N}^{\circ}$ 94/01 of 20 January 1994 to lay down forestry, wildlife and fisheries regulations which in article 16(2) stipulates that "the initiation of any development project that is likely to perturb a forest or aquatic environment shall be subject to a prior study of the environmental hazard". In 1996, three important pieces of legislation were enacted. These were:

- The Constitution of the Republic of Cameroon, which in its preamble states that "every person shall have a right to a healthy environment. The protection of the environment shall be the duty of every citizen. The State shall ensure the protection and improvement of the environment".

- The environmental management plan.

- $\quad$ The framework law on environmental management in Cameroon, Law $\mathrm{N}^{\mathrm{o}}$ 96/12 of 05 August 1996 which in article 17(1) states that:

The promoter or owner of any development, labour, equipment or project which may endanger the environment owing to its dimension, nature or the impact of its activities on the natural environment shall carry out an impact assessment, pursuant to the prescription of the specifications. This assessment shall determine the direct or indirect incidence of the said project on the ecological balance of the zone where the plant is located or any other region, the physical environment and quality of life of populations and the impact on the environment in general.

The coming into force of these laws, notwithstanding, the conduct of EIA in Cameroon remained optional or donor prescribed until 2005 when the enabling instrument of the law, Decree $\mathrm{N}^{0}$ 2005/0577/PM dated 23 February 2005, was put in place. This was complimented by orders of the Ministry in charge of the environment, namely: Order $\mathrm{N}^{\mathrm{o}}$ 0069/MINEP of 8 March 2005 to set out various categories of operations subject to the realization of environmental impact assessment; Order $\mathrm{N}^{\mathrm{o}}$ 0001/MINEP of 3 February 2007 defining the content of Terms of Reference (ToRs) for EIA; and Order $\mathrm{N}^{\mathrm{o}}$ 0002/MINEP of 3 February 2007 specifying elements of ToRs for EIA for production, plantations and community forests.

Driven by the zeal to improve on the performance of the EIA process in Cameroon and following a shift in government policy to devolve some competences to local collectivities, the instruments of application of the law governing environmental assessment in Cameroon were revised. The revision gave rise to the following texts:

- Decree $\mathrm{N}^{\mathrm{o}}$ 2012/0882/PM of 27 march 2012 to lay down terms for exercising some powers on environment transferred to councils by the state; 
- Decree $N^{o}$ 2013/0171/PM of 14 February 2013 to lay down the methodology for conducting environmental and social impact assessments;

- Decree $N^{0}$ 2013/0172/PM of 14 February 2013 to lay down methodology for conducting environmental and social audit;

- Decree $\mathrm{N}^{\mathrm{O}}$ 2015/1373/PM of 8 June 2015 to lay down rules for exercising certain powers on environment transferred by the state to councils;

- Order $\mathrm{N}^{\mathrm{o}}$ 00001/MINEPDED of 9 February 2016 to lay down the various categories of operations whose realization is subject to a strategic environmental assessment or an environmental and social impact assessment; and

- Order $\mathrm{N}^{\mathrm{o}}$ 00002/MINEPDED of 9 February 2016 to lay down the model format for the terms of reference and content of an environmental impact notice.

\section{Practice of Environmental Assessment in Cameroon}

Environmental assessment in Cameroon can be generally classed into four groups, namely; environmental and social impact assessment (ESIA), strategic environmental assessment (SEA), environmental audit (EA) and environmental impact notice (EIN) (see decrees $\mathrm{N}^{\mathrm{o}}$ 2013/0171/PM and $\mathrm{N}^{\mathrm{o}}$ 2013/0172/PM both of 14 February 2013). The strategic environmental assessment is carried out for policies, plans and programmes; environmental and social impact assessment is carried out for proposed projects (before commencement); environmental audits are carried out for existing structures; and the environmental impact notices are conducted for smaller establishments or development initiatives which do not fall in the category of operations subject to the other forms of assessment but are likely to have significant adverse effects on the environment. While the first three are coordinated at the central level, the environmental impact notices are managed at the decentralized level. The conduct of SEA is still timid, the main forms of environmental assessment practices in Cameroon being EIA, EA and EIN.

\subsection{Environmental and Social Impact Assessments (ESIA), and Environmental Audit (EA)}

As specified in the decrees governing the practice of environmental assessment in Cameroon (cited above) and Order $\mathrm{N}^{\mathrm{o}}$ 00001/MINEPDED of 9 February 2016, the reports ensuing from the conduct of environmental and social impact assessment, and environmental audit can either be summary or detailed. The order ( $\mathrm{N}^{\mathrm{o}}$ 00001/MINEPDED of 9 February 2016) serves as the screening stage of the environmental assessment procedure in Cameroon, as it groups development initiatives into categories according to the form of assessment that should be carried out owing to their dimension, nature or the impact of the activities on the natural environment. This checklist is established according to the domain of activity, scale, geographical expanse or level of investment.

The scoping phase which actually appears to be the start of the environmental assessment process in Cameroon (Figure 1) is done by the proponent or proprietor of the development venture, most often through a consultant or consulting firm. The terms of reference (ToRs) are prepared which also serve as the initial environmental assessment for the ESIA or EA. 


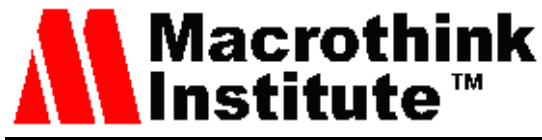

The process formally begins with the submission of an application file to MINEPDED comprising of the ToRs, a schedule on how the population in the environs of the project site will be consulted and a receipt attesting the payment of the required review fees. MINEPDED makes its pronouncement on the application by either outright approval, approval on condition or utter rejection.

Next, is the organization of consultation of the riverine population of the project site either by the proponent or owner of the project or by a consultant contracted for the purpose. These consultations take place in the form of meetings with the riverine populations and other relevant stake holders such as representatives of other sectoral ministries (Nguene et al., 2012). The end product of the public consultation are minutes duly signed by attendees. -

On approval of the ToRs, the proponent or owner of the project necessarily contracts the services of a consultant for the subsequent steps of the assessment process and the consultant must be one registered with MINEPDED. The study proceeds with the production of a report. This entails the collection of secondary and field data, identification and prediction of impacts, proposal of mitigation measures and production of an environmental management plan (EMP). The completed (ESIA or EA) report is submitted for review to MINEPDED and the Ministry in charge of the sector of activity concern, elsewhere referred to as the competent administration. The report is submitted alongside with minutes of the public consultations and a receipt showing proof of payment of examination fees. MINEPDED then organizes a joint review mission with the competent administration in order to cross-check the field realities with the stipulation of the report. Based on the findings of the field mission, MINEPDED declares whether the report is admissible or not.

For assessments requiring a detailed study, MINEPDED proceeds with the organization of public hearings if the report is declared admissible. The exercise is intended to record the views of the affected and interested populations, earlier consulted, on the content of the report. It consists of making copies of the report available to members of the population, to individually exploit in reading rooms set up for the purpose. Observations are entered in registers, which are exploited at a later stage in the process. A summary report of the participation and observations of the population during the public hearings (where necessary) is submitted alongside the main ESIA or EA report (by MINEPDED) for scrutiny to the Inter-Ministerial Committee for the Environment (ICE). The opinion of the ICE on the report and summary of the public hearings, where appropriate, forms the basis for the final decision to be made by MINEPDED on the assessment which could be favourable, approved on condition or outright rejection. A favourable decision leads to the issuance of a Certificate of Environmental Compliance (CEC).

The implementation of the environmental management plan is monitored by committees set up by MINEPDED in the Divisions hosting the projects. Members of these committees, headed by the Senior Divisional Officers of the respective Divisions are drawn from the deconcentrated services of MINEPDED, the competent administration and the civil society. The committees are expected to submit monitoring reports to MINEPDED every semester. 


\section{Macrothink

\subsection{Environmental Impact Notice (EIN)}

The conduct of the EIN (figure 2) is supervised by local collectivities (Councils) and the deconcentrated services of MINEPDED. The screening for projects subject to environmental impact notices is done by the councils which draw up a list for such project as per the specificities of their localities. Order $\mathrm{N}^{\mathrm{o}}$ 00002/MINEPDED of 9th February 2016 gives a framework for such projects and activities that serves as a guide to the councils. The EIN process begins with the submission of an application file by the promoter of the activity or his consultant to the competent council against a receipt. The application file comprises of a written application, four copies of the ToRs and a payment slip of the review fees. Copies of the ToRs are forwarded to the Divisional Delegation of MINEPDED for its technical opinion that will guide the decision of the Council on the ToRs.

Upon approval of the ToRs, the promoter of the activity or his consultant proceeds with the production of the EIN report. The report is submitted, against a receipt, to the territorially competent Council that forwards copies to the Divisional Delegate of MINEPDED and the Divisional Delegate of the competent Ministry. The competent sector Delegation forwards its technical opinion on the file to the Delegate of MINEPDED who in turn gives his opinion to the Council within a stipulated time frame. If approved, the Council then issues a Certificate of Environmental Compliance to the promoter of the structure. 

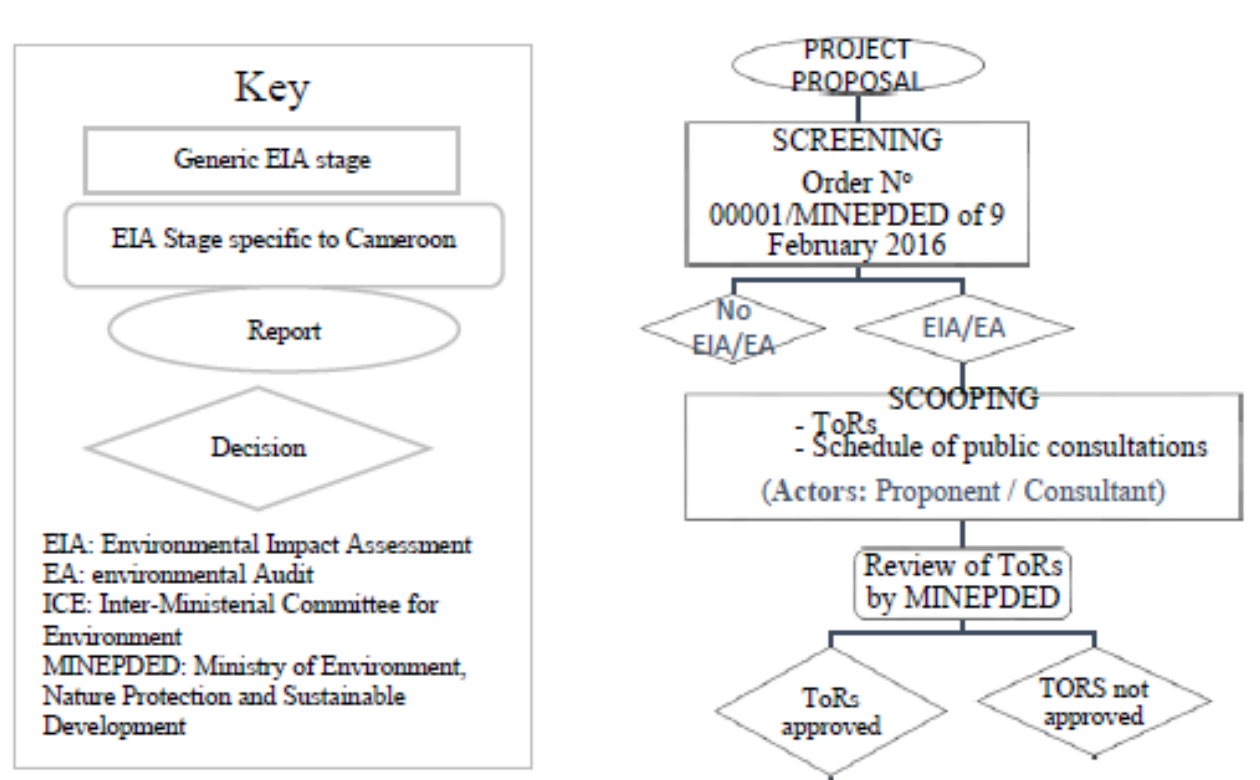

Public Consultations

(Actors: Proponent, Consultant and stakeholders)

IMPACT ANALYSIS, MITIGATION and MANAGEMENT

(Actors: Consultant and proponent)

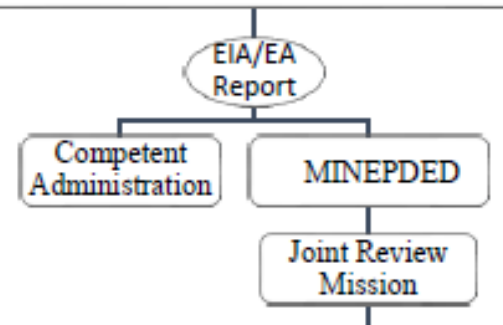

Public Hearings

(Actors: MNEPDED,

Consultant, Stakeholders)

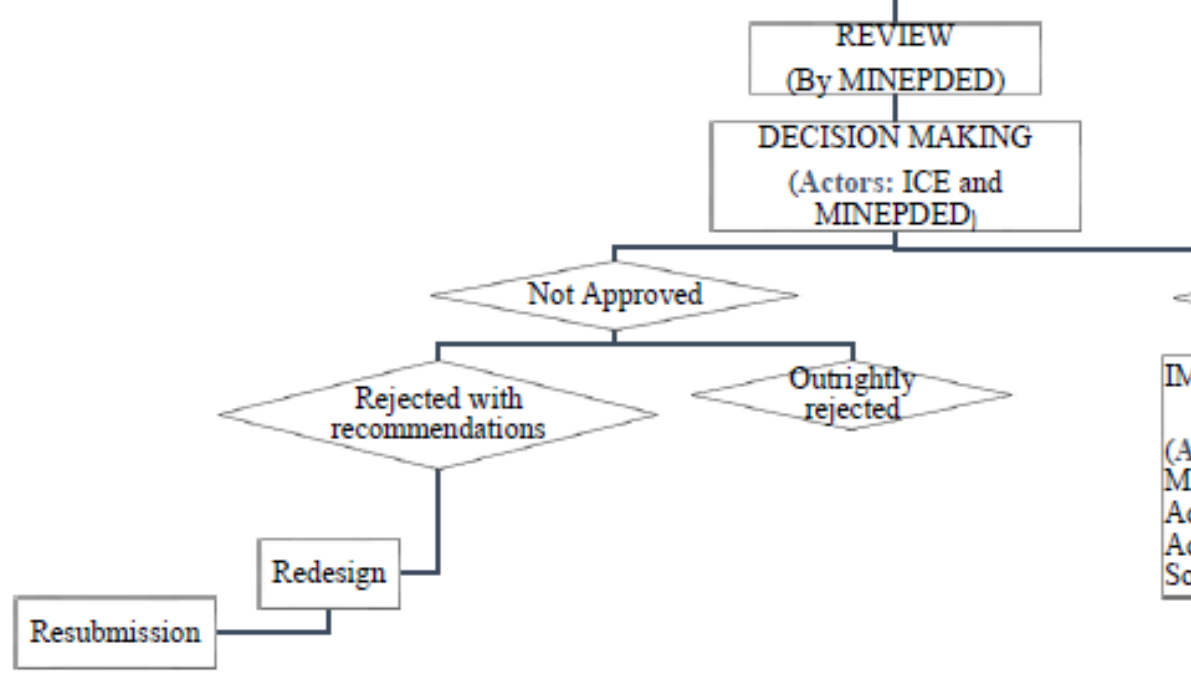

Figure 1. Flow chat of Environmental and Social Impact Assessment (ESIA) and Environmental Audit (EA) in Cameroon 

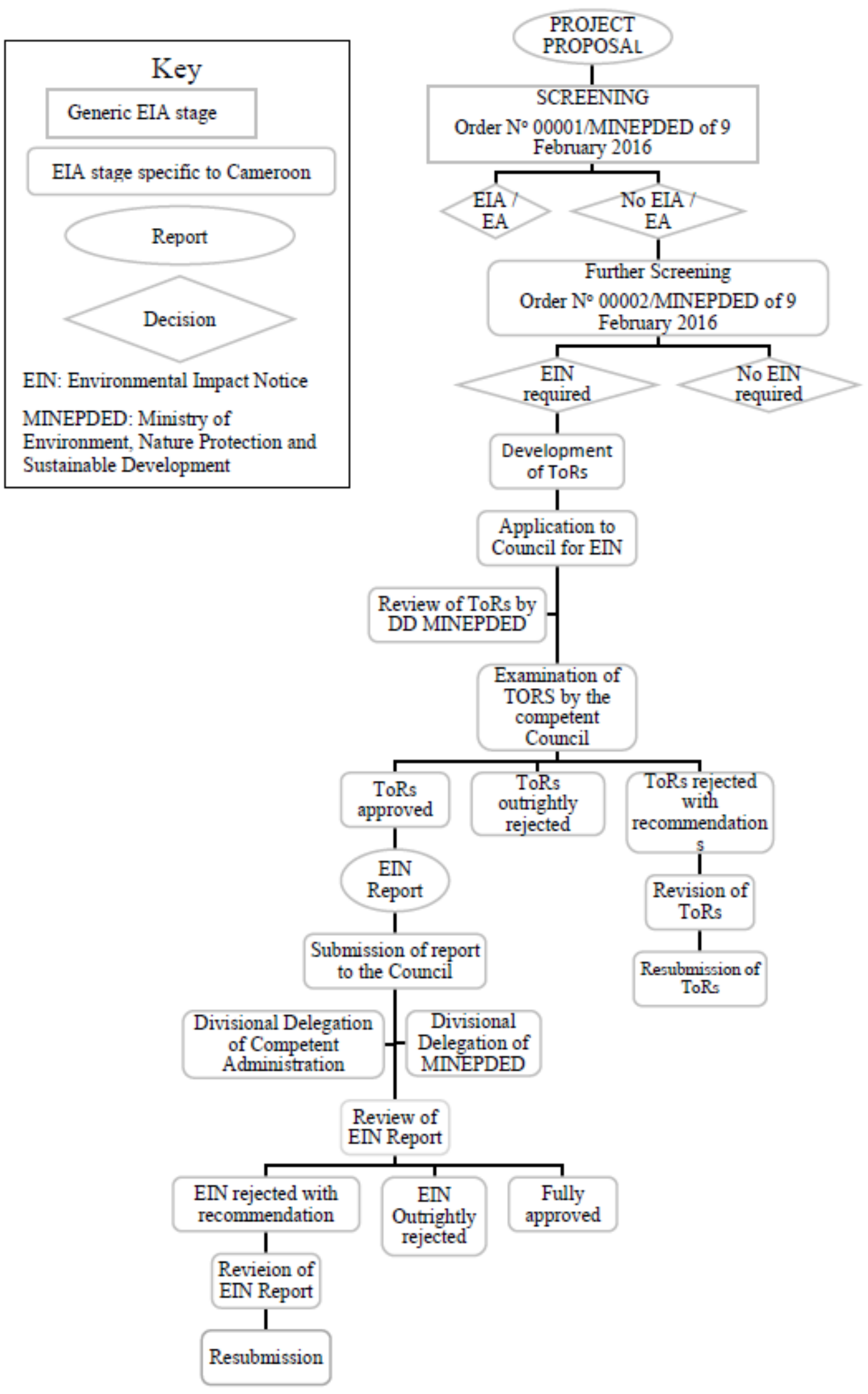

Figure 2. Flow chat of Environmental Impact Notice (EIN) in Cameroon 


\section{Macrothink \\ Environmental Management and Sustainable Development \\ ISSN 2164-7682 \\ 2021, Vol. 10, No. 1}

\section{Challenges to the Effectiveness of Environmental Assessment in Developing Countries}

Challenges such as technical shortcomings, procedural limitation and structural issues could be considered common or general to the conduct of EIA even in developed countries (UNEP, 2002). Many authors have identified challenges in the EIA procedure that are very peculiar to developing countries. For instance, in Cameroon (Alemagi et al., 2007; Bitondo, 2000; Ngouana Kengne, 2009; Nguene et al., 2012), Egypt (Badr, 2009), Ghana (Appiah-Opoku, 2001; Barimah, 2014), Malawi (Kosamu et al., 2013), Pakistan (Nizami et al., 2011), South Africa (Sandham et al., 2005), Tanzania (Mwakaje, 2013), and very generally for all developing countries (Betey \& Essel, 2013; Farrell et al., 2001; Haklay, 2003; Kamijo \& Huang, 2017; UNEP, 2002). The major constraints linked to the conduct of environmental assessment in developing countries, identified in this study and from literature consulted, among others, include the following:

- Paucity in (environmental) baseline data;

- Insufficient environmental assessment experts;

- Institutional insufficiencies;

- Procedural lapses;

- General lack of awareness on environmental issues and EIA procedure;

- Illiteracy among the local populations;

- Lack of provision for proponents to appeal against decision;

- Absence or ineffective public participation;

- Deficiency of direct investment in project communities;

- Corruption, lack of transparency and accountability;

- Discrepancies between legal provisions and practice;

- Insufficient funds;

- Inadequate follow up of mitigation and environmental management plans;

- Huge volumes of EIA reports often written in technical language;

- Insufficient consideration of alternatives;

- Low rate of implementation of recommended mitigating measures;

- Start of development projects before the approval of the EIA; and

- Inadequate assessment of cumulative and long term impacts.

\section{Discussion}

The conduct of environmental assessment in Cameroon has witnessed a remarkable improvement since its inception. It has evolved from being a mere prescription of donor and 
development agencies to being mandatory (Alemagi et al., 2007; Bitondo, 2000). The current legislation has expressly included assessment at the policy, plan and programme level while the assessment at project level has been clearly stratified and part of the exercise decentralized. Some clarity has also been made on the categories of projects to be subject to the different forms of assessment - EA, ESIA and EIN. This improvement notwithstanding, much still has to be done to make environmental assessment in the country fully play its role as a veritable tool to fast tract sustainable development.

Unlike what obtains in other developing countries where the environmental assessment process is controlled and supervised by a separate independent body, such as in Egypt (Badr, 2009) and Ghana (Barimah, 2014), in Cameroon it is handled by the Ministry in charge of environment which is already overladen with other administrative exigencies. Adequate involvement of the public has been pointed out as good practice in handling environmental issues and ensuring durable development (Betey \& Essel, 2013). Nguene et al. (2012), however, notes that public participation in the EIA process in Cameroon fails to take into consideration certain realities of the communities hosting project sites. This failure definitely impacts on the contribution of the public to the ESIA/EA process and its leverage in contributing to sustainable development. Betey and Essel also suggest that public participation and the consideration of alternative project designs constitute key ways in which environmental assessment can make meaningful contribution to sustainable development. The consideration of alternatives especially the no-action alternative in the environmental assessment process in Cameroon tends to be limited.

The follow-up of the implementation of mitigation actions and the recommendations of the decision-making authority is crucial for the effectiveness of an assessment system. In Cameroon, the practice does not quite tie with theory, as provided by regulations. This is in consonance with the observation made by Kamijo and Huang (2017) that weak enforcement of environmental assessment findings is a major problem in developing countries. As a consequence, ineffective environmental assessment fails to yield the desired fruits. The weakness of ineffective environmental assessment was also observed by Mwakaje (2013) who stated that despite the fact that EIA had been carried out before the implementation of foreign development investment projects in Tanzania, the projects had far reaching negative effects on the social, economic and environmental spheres.

Procedural aspects, institutional capacity and competence of practitioners define an effective EIA system (Mwakaje, 2013). This requires diligence in the conduct of the exercise, full involvement of the public as early as possible and throughout the process, consideration of alternatives, compliance of practice with regulation, a well-structured regulatory authority and an adequate skilled staff, effective monitoring and enforcement of regulations (Betey \& Essel, 2013; Bitondo, 2000; Kamijo \& Huang, 2017). Mwakaje further pointed out that to ensure that environmental assessments fully take economic, environmental and socio-cultural concerns on board in order to meaningfully contribute to sustainable development, it should incorporate the precautionary, democratic, polluter-pay and liability principles of environmental management. 


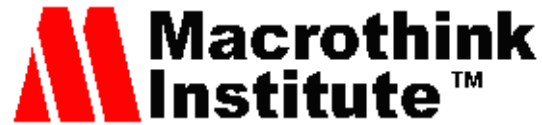

Owing to the poverty situation and prevalence of corruption in developing countries, economic and political reasons often override environmental considerations in the design and implementation of projects. The consideration of alternatives especially the no-action alternatives are at times not given adequate attention (Wood, 2003). The riverine population may let go some of their rights in exchange of short term benefits and pleasantries or the population is suppressed or intimidated by the local administration.

The practice of SEA in Cameroon and many developing countries is still at its infancy. It was formally introduced in Cameroonian regulation in 2013. Alshuwaikhat (2005) advocates for the adoption of SEA in developing countries in a bid to check and correct the limitations of environmental assessment at project level. This author and many others, for example, Partidário (2003), Sadler (2001) and Sadler and Verheem (1996) have advocated for the full adoption of SEA because of the accrued benefits. Some of the advantages of the implementation of SEA, as pointed out by these authors, among others include: the incorporation of environmental and sustainability concerns into decision making at the initial and highest stage; better consideration of cumulative impacts; ordering of environmental actions; screening of projects and consideration of alternatives; and setting the context for and improving lower level assessments. Alshuwaikhat notes that SEA is proactive, as it can be used in the screening of projects and guiding selected projects before some crucial decisions are made such as site selection and financing.

\section{Conclusion and Recommendations}

Many developing countries, Cameroon inclusive, are well on course and have made tremendous strides in the implementation of environmental assessments systems. This improvement notwithstanding still leaves room for more to be done for such assessments to fully play the role of facilitating sustainable development. Effective environmental assessments result in a win win situation for the investors, governments and the local communities where projects are carried out.

Sustainable development and poverty alleviation could be reasonably enhanced in developing countries through the implementation of effective environmental assessment systems. These systems can be improved by: tailoring the environmental assessment process to reflect the prevailing conditions; developing a viable baseline; building capacity; strengthening institutions that coordinate environmental assessments; beefing up the legal framework to include incentive and coercive measures; enhancing awareness creation on environmental issues; improving public participation and follow-up; and enhancing assessment of cumulative and strategic impacts.

\section{References}

Abaza, H., Bisset, R., \& Sadler, B. (2004). Environmental impact assessment and strategic environmental assessment: towards an integrated approach. UNEP/Earthprint.

Alemagi, D., Sondo, A. V., \& Ertel, J. (2007). Constraints to environmental impact assessment practice: A case study of Cameroon. Journal of Environmental Assessment Policy and Management, 9(3), 357-380. https://doi.org/10.1142/S1464333207002809 
Alshuwaikhat, M. H. (2005). Strategic environmental assessment can help solve environmental impact assessment failures in developing countries. Environmental Impact Assessment Review, 307-317. https://doi.org/10.1016/j.eiar.2004.09.003

Appiah-Opoku, S. (2001). Environmental Impact Assessment in Developing Countries: the case of Ghana. Environmental Impact Assessment Review, 21, 59-71.

https://doi.org/10.1016/S0195-9255(00)00063-9

Badr, A. E.-S. (2009). Evaluation of the environmental impact assessment system in Egypt. Impact Assessment and Project Appraisal, 27(3), 193-203.

https://doi.org/10.3152/146155109X465959

Barasa, P. J. (2016). Environmental impact assessment - General procedures. SDG Short Course I on Exploration and Development of Geothermal Resources, Lake Bogoria and Lake Naivasha, Kenya.

Barimah, T. P. (2014). Quality of Environmental Impact Statements in Ghana. Journal of Environment and Earth Science, 4(21).

Betey, B. C., \& Essel, G. (2013). Environmental Impact Assessment and Sustainable Development in Africa: A Critical Review. Environment and Natural Resources Research, 3(2). https://doi.org/10.5539/enrr.v3n2p37

Bitondo, D. (2000). Environmental assessment in Cameroon: state of the art. Impact Assessment and Project Appraisal, 18(1), 33-42.

https://doi.org/10.3152/147154600781767592

Farrell, A., VanDeveer, D. S., \& Jager, J. (2001). Environmental assessments: four under-appreciated elements of design. Global Environmental Change, 11, 311-333.

https://doi.org/10.1016/S0959-3780(01)00009-7

Haklay, E. M. (2003). Public access to environmental information: past, present and future. Computers, Environment and Urban Systems, 27, 163-180.

https://doi.org/10.1016/S0198-9715(01)00023-0

Kamijo, T., \& Huang, G. (2017). Focusing on the Quality of EIS to Solve the Constraints on EIA Systems in Developing Countries: A Literature Review. JICA Research Institute working paper.

Kosamu, I. B. M., Mkandawire, A. A., Utembe, W., \& Mapoma, H. W. T. (2013). Public participation in Malawi's environmental impact assessment (EIA) process. African Journal of Environmental Science and Technology, 7(5), 307-311.

https://doi.org/10.5897/AJEST13.1447

Mwakaje, G. A. (2013). Assessing the Contribution of Environmental Impact Assessments in Informing Decision Makers Concerning the Booming of FDI in Tanzania. Environment and Natural Resources Research, 3(4). https://doi.org/10.5539/enrr.v3n4p118

Ngouana Kengne, V. C. (2009). Environmental compliance and monitoring of Petroleum 
development and pipeline project in developing countries: A case study of Chad-Cameroon pipeline project. Accra.

Nguene, F. R., Fonocho, C. E., Lebongwo, J. T.-A., \& Nien, S.-A. N. (2012). Role and level of stakeholders involvement in the EIA practise in Cameroon: Case of EIAs of the upstream energy sector.

Nizami, A.-S., Molander, S., Asam, Z.-u.-Z., Rafique, R., Korres, N. E., Kiely, G., \& Murphy, J. D. (2011). Comparative analysis using EIA for developed and developing countries: case studies of hydroelectric power plants in Pakistan, Norway and Sweden. International Journal of Sustainable Development \& World Ecology, 18(2), 134-142.

https://doi.org/10.1080/13504509.2011.559399

Parker, S. P., \& Corbit, R. A. (1993). McGraw - Hill Encyclopedia of Environmental Science \& Engineering. McGraw - Hill.

Partidário, R. M. (2003). Strategic Environmental Assessment (SEA) current practices, future demands and capacity-building needs. International Association for Impact Assessment IAIA Training Courses.

Sadler, B. (2001). A Framework Approach to Strategic Environmental Assessment: Aims, Principles and Elements of Good Practice. In J. Dusik (Ed.), Proceedings of International Workshop on Public Participation and Health Aspects in Strategic Environmental Assessment (Vol. 11, pp. 11-24). The Regional Environmental Center for Central and Eastern Europe.

Sadler, B., \& Verheem, R. (1996). Strategic Environmental Assessment: Status, Challenges and Future Directions. 53, The Hague, Netherlands.

Sandham, A. L., Siphugu, M. V., \& Tshivhandekano, R. T. (2005). Aspects of Environmental Impact Assessment (EIA) Practice In the Limpopo Province - South Africa. AJEAM-RAGEE, 10, 50-65.

UNEP. (2002). Environmental Impact Assessment Training Resource Manual. United Nations Environment Programme.

United Nations. (1992). Report of the United Nations Conference on Environment and Development: Rio Declaration on Environment and Development (Annex 1). Rio de Janeiro.

United Nations. (2016). Transforming our world: The 2030 agenda of sustainable developm. A/RES/70/1.

Wood, C. (2003). Environmental Impact Assessment in developing countries: An overview. New Directions in Impact Assessment for Development: Methods and Practice, Manchester. https://doi.org/10.3828/idpr.25.3.5 


\section{Macrothink \\ Environmental Management and Sustainable Development \\ ISSN 2164-7682}

\section{Copyright Disclaimer}

Copyright for this article is retained by the author(s), with first publication rights granted to the journal.

This is an open-access article distributed under the terms and conditions of the Creative Commons Attribution license (http://creativecommons.org/licenses/by/4.0/). 